\title{
Community Structure of Seagrass in Harapan Island, Seribu Islands, Indonesia
}

\author{
Ratih Ida Adharini1*, Tesya Ranma Yuniarga1, Nindya Larasaty Prasetya1 ${ }^{1}$, Faizal Rachman² \\ ${ }^{1}$ Lab. Aquatic Resources Management, Fisheries Department, Faculty of Agriculture, Universitas Gadjah Mada \\ Jl. Flora 1 A Bulaksumur Depok, Sleman, Yogyakarta Indonesia \\ ${ }^{2}$ College of the Environment and Ecology, Xiamen University \\ 422 Siming S Rd, Si Ming Qu, Xia Men Shi, Fu Jian Sheng, 361005 China \\ Email : ratih.adharini@ugm.ac.id
}

\begin{abstract}
Seagrass is an aquatic biota that is ecologically and economically beneficial. This study aims to determine the community structure of seagrass in Harapan Island, Seribu Islands, Indonesia. The research was conducted using purposive sampling method, that divided into two sites which is considered to represent the ecology's condition of Harapan Island. The site 1 was located adjacent to the mangroves area, while the site 2 was placed near a reclamation development and ship anchoring. Every site had three subsites as replications, each was 50 meters apart. Water parameters temperature, salinity, turbidity, $\mathrm{pH}$, dissolved oxygen (DO), depth, and organic compound of each site were measured. The results showed that coverage of seagrass in site 2 is higher than site 1 that categorized as frequent-common coverage. The site 2 had the density of 220 individuals seagrass per square meter that dominated by Cymodocea rotundata. The highest diversity index was found in the site 1 at 1.15, with the lowest dominance index being 0.39. The distribution pattern in site 1 is clustered and uniform, while site 2 is uniform. The Importance Value Index in site 1 was 114,8 by Halodule uninervis, while site 2 was 125,5 by C. rotundata. It is thought that the low diversity of seagrass at the site 2 due to it was near a reclamation development and ship anchoring that disturb the abundance and community structure of seagrass in Harapan Island. Habitat destruction and anthropogenic impact of seagrass need to be minimized to support environmental coastal and fisheries sustainability.
\end{abstract}

Keywords: coverage, density, diversity, Harapan Island, seagrass

\section{Introduction}

Seagrass is a flowering plant that is an essential part of aquatic food webs, helps to mitigate climate change, and supports biodiversity (Irawan et al., 2018; Unsworth et al., 2019). Seagrass support biodiversity by providing food for herbivores, grazers, and predators (Hartati et al., 2017; Scott et al. 2018). Seagrass has high productivity that reach $6825 \mathrm{gcm}$ $2 y^{-1}$ (McRoy and McMillan, 1977). Van Dam et al. (2020) found that seagrasses can exchange water and carbon dioxide in shallow tropical and subtropical waters much better than other submerged vegetations.

Seagrass can be found in shallow oceanic coastlines worldwide, except Antarctica (Pham et al., 2016). The Tropical-Indo Pacific Zone has the highest seagrass diversity globally, with 24 species in shallow to deep waters (Short et al., 2007). According to Yaakub et al. (2018), seagrass are typically found in relatively shallow waters, covered beaches, and throughout extensive estuaries in Southeast Asia, including Indonesia. The pattern of decline in seagrass ecosystems has accelerated globally due to the growth of human population and climate changes that put environmental pressures on coastal areas (Short et al., 2007; Evans et al. 2018; Sugianti and Mujiyanto, 2020). Eventhough seagrass population is also affected by natural disturbance (Ahmad-Kamil et al. 2013). Environmental factors play a critical role in determining the location and growth of seagrasses (Yaakub et al., 2018). McCloskey and Unsworth (2015) explained that the loss of seagrass was caused by physical disturbances, which in turn caused habitat degradation. According to the Oceanographic Research Center (P2O) of the Indonesian Institute of Sciences (LIPI), there are 15 types of seagrass found in Indonesia, but only nine of them are easy to observe (LIPI, 2016). At the same time, most seagrass fields in Indonesia are within unhealthy conditions. Of the 37 locations sampled, 27 were less healthy, five were not healthy, and the remaining were in good conditions.

Seagrass fields can be found in most of the island's waters within the Kepulauan Seribu National 
Park (TNKpS) area, such as Pramuka Island, Panggang Kelapa Island, and Harapan Island. Research on seagrass in Pramuka Island found seven seagrass species that are part of the family Potamogetonaceae and Hydrocharitaceae (Haviarini et al., 2019). The continued pressure leads to ecosystem decline, decreased seagrass conditions, and diminishing seagrass' ecosystem function (Unsworth et al., 2019). Therefore, monitoring the seagrass ecosystem from the impact of ecosystem changes that happened in Kepulauan Seribu is needed. This study aims to determine the structure of seagrass communities including coverage, species composition, density, diversity and dominancy, distribution pattern, and important value index in Harapan Island, Kepulauan Seribu.

\section{Materials and Methods}

The study sites were selected using the purposive sampling method. that divided into two sites which is considered to represent the ecology's condition of Harapan Island. The site 1 was located adjacent to the mangroves area, while the site 2 was placed near a reclamation development and ship anchoring. See Figure 1.

Every site has three subsites as replications, each was 50 meters apart. The transects was stretched perpendicular to the coastline along 100 meters which was divided into 10 observation plots $(0.5 \mathrm{~m} \times 0,5 \mathrm{~m})$ that performed at the lowest low tide. Seagrass data was taken once at the beginning of data retrieval performed at each plot in two sites and six subsites, i.e., the number of stands of each type.

Coverage of seagrass is determined using this formula by Rahmawati et al. (2014). The coverage of seagrass then categorized by Rahmawati et al. (2014) where: $0 \%-25 \%$ is rare; $26 \%-50 \%$ is frequent; $51 \%-75 \%$ is common; $76 \%-100 \%$ is abundance.

Seagrass samples in each plots were taken and put into plastic bags that have been labeled as markers for identification and documentation. Seagrass was identified by the book "Seagrass Monitoring Guide" by Rahmawati et al. (2014).

Seagrass density (Di) is the number of seagrass individuals per unit area. The density of each type at each site is calculated using a formula (Brower et al., 1998):

$$
\boldsymbol{D} \boldsymbol{i}=\frac{\boldsymbol{n i}}{\boldsymbol{A}}(\mathrm{ind} / \mathrm{ha})
$$

Note: $D i=$ the number of individuals (stands) seagrass $i$ per unit area; $n i=$ the number of individuals (stands) seagrass $i$ in the squared transect; $A=$ the area of the quadratic transect.

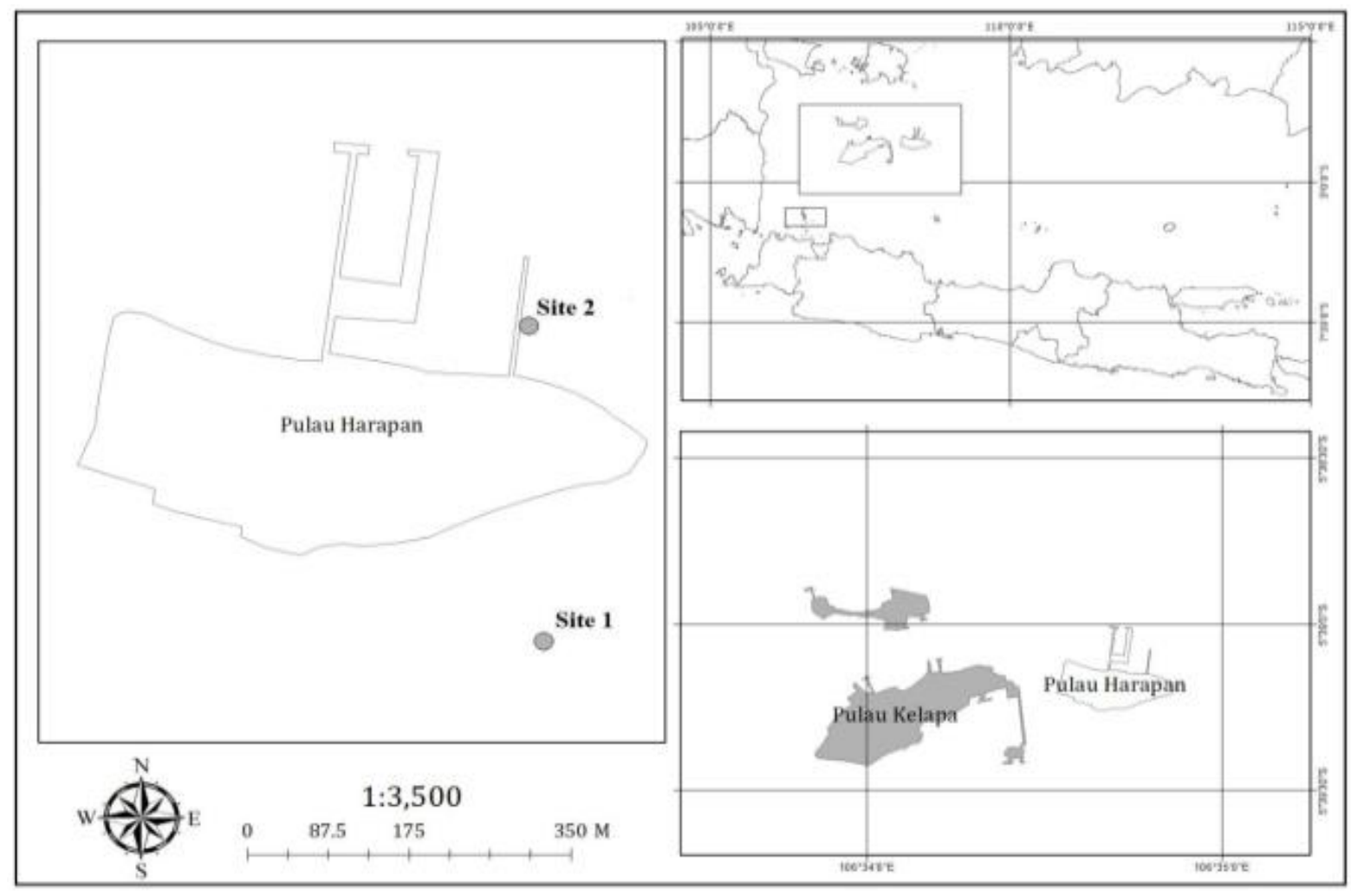

Figure 1. Seagrass study sites in Harapan Island, Seribu Islands 


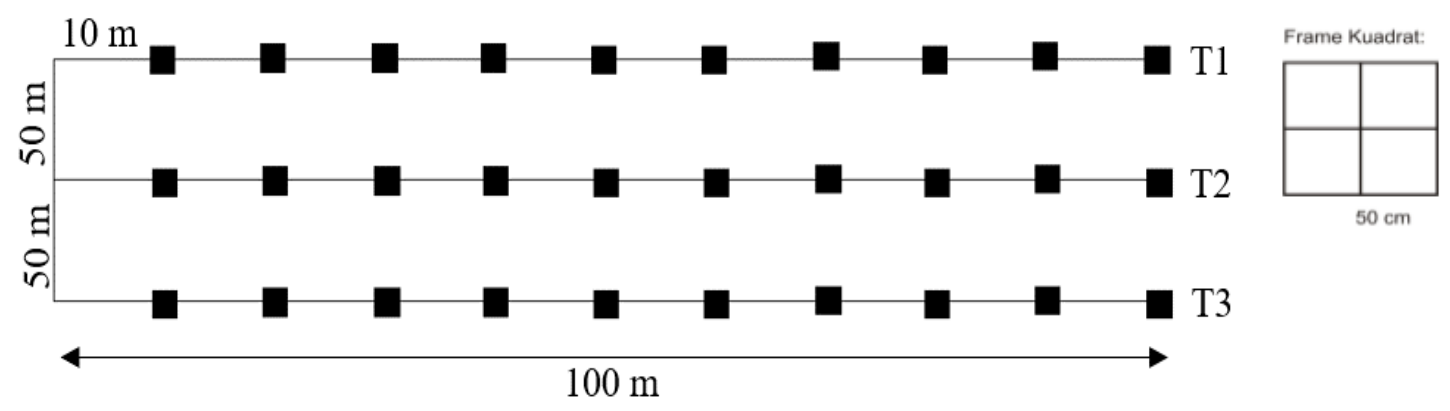

Figure 2. Transect position in each site in Harapan Island, Indonesia

Calculation of seagrass species diversity index using Shannon-Wiener diversity formula (Brower et al., 1998):

$$
H^{\prime}=-\sum_{i=1}^{n} P i x \log P i
$$

Note: $\mathrm{H}^{\prime}=$ Diversity Index; $\mathrm{Pi}=\mathrm{Ni} / \mathrm{N} ; \mathrm{Ni}=$ the number of individuals (stands) seagrass $-i$ in the squared transect; $N=$ number of individuals of all species. The diversity index then categorized following this criteria: $\mathrm{H}^{\prime}<1=$ low diversity;

\section{$1 \leq \mathrm{H}^{\prime} \leq 3=$ moderate diversity; $\mathrm{H}^{\prime}>3$ =high diversity}

The dominance index formula is used to determine whether or not a particular type is dominant following Simpson Index of Dominance (Brower et al., 1998):

$$
D=(\Sigma P i)^{2}
$$

Note: $D=$ Dominance Index; $\mathrm{Pi}=\mathrm{Ni} / \mathrm{N} ; \mathrm{Ni}=$ number of individuals (stands) seagrass $i$ in the squared transect; $N=$ Total number of individuals of all species. The diversity index then categorized following this criterion: $\mathrm{D}<0,4=$ low dominancy; $0,4 \leq$ $\mathrm{H}^{\prime} \leq 0,6=$ moderate dominancy; $\mathrm{D}>0,6=$ high dominancy.

The distribution pattern of seagrass is determined by calculating Morisita Dispersion Index (Brower et al. 1998) with the equation:

$$
I d=\frac{n\left(\sum_{i=1}^{x} x^{2}-N\right)}{N(N-1)}
$$

Note : $I d=$ Morisita Dispersion Index; $n=$ the number of sample plots; $N=$ the number of individuals in $n$ plots; $x=$ the number of individuals on each plot. The seagrass dispersion pattern is determined by Morisita Index which using the following criteria (Brower et al., 1998):

Id $<1$ = uniform dispersion pattern; $I d=1$ = random dispersion pattern; $I d>1$ = cluster dispersion pattern.
The Important Value Index (IVI) results from the summation of relative density and relative frequency, which indicate the ecological standing of a species in a community.

$$
\mathrm{IVI}=\text { Relative density }+ \text { relative frequency }
$$

Relative density

$=\frac{\text { Density value of a particular species }(\mathrm{ni})}{\text { Total density value of all species }\left(\sum \mathrm{n}\right)} \times 100 \%$

Relatif frequency

$=\frac{\text { Frequency value of a particular species (ni) }}{\text { Total frequency value of all species }} \times 100 \%$

Environmental parameters of the observed waters include water temperature, salinity, brightness, depth, and organic matter were observed in both locations.

\section{Result and Discussion}

\section{Percent coverage of seagrass}

Coverage of seagrass in the site 2 is higher than in the site 1 . The average of percentage coverage of seagrass in site 2 is $45,83 \%$, while site 1 is $26,46 \%$. Coverage of seagrass in the site 1 based on Rahmawati et al. (2014) is categorized as frequent coverage. While the site 2 is categorized as frequentcommon coverage. Based on Decree of Indonesian Minister of Environment No 200 in 2004, site 1 is categorized as unhealthy, while site 2 is less healthy (Figure 3.).

Site 2 has higher seagrass coverage but lower of diversity than site 1 . The higher coverage of seagrass in site 2 was dominated by $C$. rotundata which has high tolerance to environmental pressure. The lower diversity in site 2 presumably because it is affected by reclamation and ship anchoring, which led to the destruction of the seagrass habitat.. Physical disruption to seagrass ecosystems can trigger seagrass fragmentation or fracture, decrease in density, height, seagrass cover, and potentially eliminate biota habitats therein (McCloskey and Unsworth, 2015). Meanwhile Ahmad-Kamil et al. 
(2013) stated that percentage cover of seagrass also affected by weather as natural disturbances. However, this study also showed that certain types of seagrass species have a high tolerance to environmental pressures that occur in the presence of high of organic compound in site 2. It is also evidenced by the higher dominance index at site 2 is due to $C$. rotundata domination which is resistance to polluted water conditions. But different result reported by Aboud and Kannah (2017) that unprotected area had higher seagrass coverage than protected area because of predation and grazer activities in protected area.

\section{Seagrass species composition}

Five seagrass species were discovered in site 1, i.e., Cymodocea rotundata, Cymodocea serrulate, Halodule uninervis, Syringodium isoetifolium, and Thalasssia hemprichii, which belong to Cymodoceaceae and Hydrocharitaceae families. In comparison, there were three species found in site 2 , i.e., C. rotundata, $H$. uninervis, and $T$. hemprichii (Table 1.).

All of those seagrasses in both sites are classified into the Alismatales order. The Hydrocharitaceae family was also found on Pramuka Island, Kepulauan Seribu (Haviarini et al. 2019). Both islands have almost the same aquatic conditions and match the seagrass habitat of this family. Genus of Cymodocea, Thalassia and Halodule were found in both 2 sites, while Genus of Syringodium were found only in site 1 . Therefore, site 1 has a more supportive environment for the existence of various seagrass than at site 2 .

\section{Density, diversity, and dominancy index of seagrass}

The highest density of seagrass at site 1 is $H$. universis. The highest density of seagrass at site 2 is C. rotundata, meanwhile the density of $C$. rotundata in site 1 were very low (Figure 4.). This is showed that C. rotundata grow dominantly in site 2 than other species.

The average diversity index and dominancy index in Harapan Island are 1.03 and 0.43 , and both are within a moderate level, respectively (Figure 5). Site 1 has higher diversity index than site 2 because site 1 consist of 5 different species of seagrass, while site 2 only has 3 different species.

$H$. uninervis is mostly found in site 1 with sand and coral rubble, which agrees with the studies by Short et al., (2007) and Haviarini et al., (2019). Halodule inhabit in shallow water with little salinity fluctuation (Copertino et al. 2016). Site 2 is an intertidal zone with a relatively narrow tidal area, and the construction of concrete walls and reclamation also narrowed the tidal zone at this study site. This zone is heavily overgrown by $C$. rotundata.

According to Haviarini et al. (2019), C. rotundata has a habitat preference in intertidal zones with a narrow area between the highest and lowest tidal areas. $T$. hemprichii is found in both sites, and this indicates that $T$. hemprichii matches the environmental conditions. Fitrian et al. (2017) state that $T$. hemprichii has a wide range of water conditions tolerance and can live on various substrates. However, Tupan and Uneputty (2018)

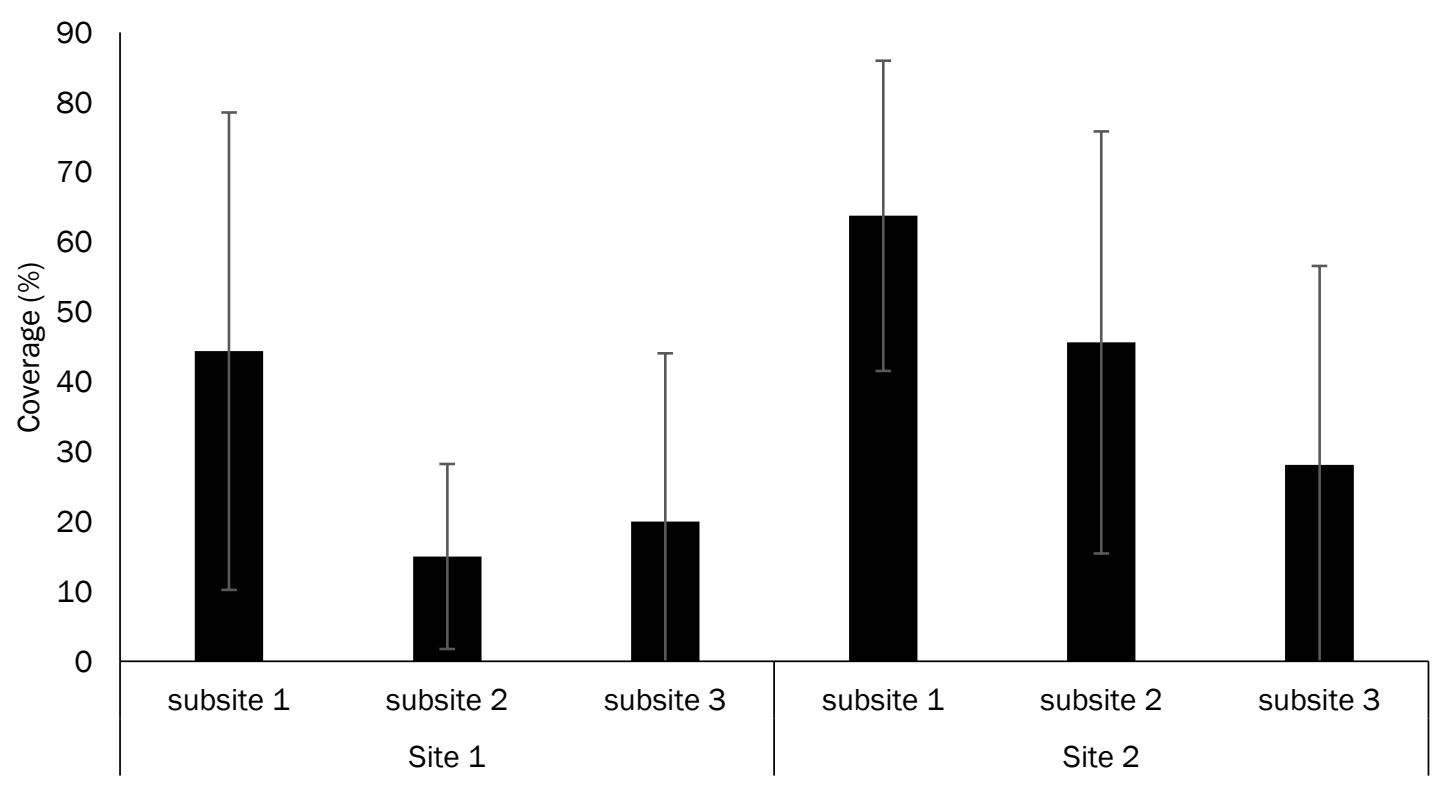

Figure 3. Coverage of seagrass in two study sites in Harapan Island 
ILMU KELAUTAN: Indonesian Journal of Marine Sciences March 2022 Vol 27(1):20-28

Table 1. Species composition of seagrass in two study sites in Harapan Island

\begin{tabular}{|c|c|c|c|c|}
\hline Sites & Order & Family & Genus & Species \\
\hline \multirow[t]{5}{*}{ Site 1} & Alismatales & Cymodoceaceae & Cymodocea & Cymodocea rotundata \\
\hline & & & & Cymodocea serrulata \\
\hline & & & Halodule & Halodule uninervis \\
\hline & & & Syringodium & Syringodium isoetifolium \\
\hline & & Hydrocharitaceae & Thalassia & Thalassia hemprichii \\
\hline \multirow[t]{3}{*}{ Site 2} & Alismatales & Cymodoceaceae & Cymodocea & Cymodocea rotundata \\
\hline & & & Halodule & Halodule uninervis \\
\hline & & Hydrocharitaceae & Thalassia & Thalassia hemprichii \\
\hline
\end{tabular}

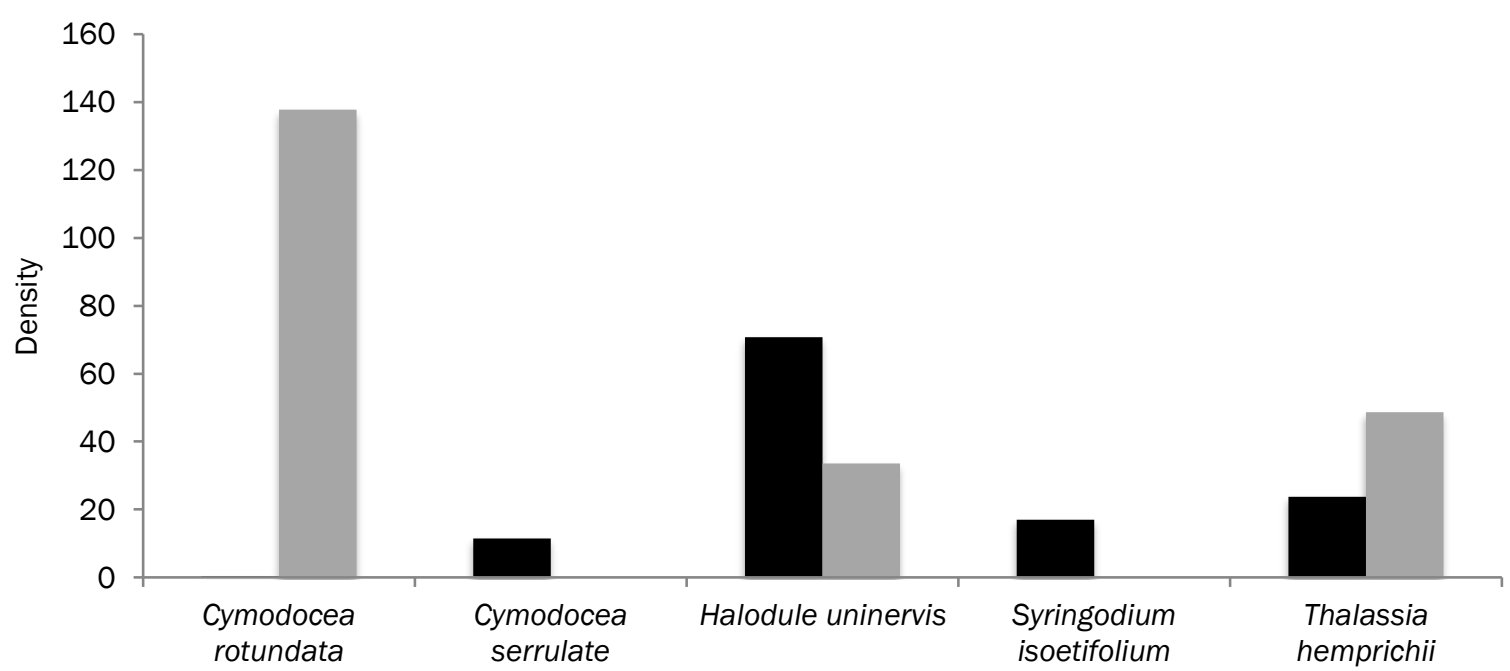

- Site $1 \quad$ Site 2

Figure 4. The Density (b) of seagrass in Harapan Island

state that this seagrass type tends to thrive in sandy substrates rather than muddy substrates, and predominantly grows in substrate waters of coral shards (Short et al., 2007).

\section{Important Value Index of seagrass}

Seagrass species found on Harapan Island have different indices of important values. See Table 2. Species of $H$. uninervis has the highest IVI rating at site 1 (114.8\%) but the lowest at the site 2 (30.53\%). It is inversely proportional to $C$. rotundata, which has the lowest IVI at site $1(0.32 \%)$, and the highest at site $2(125.2 \%)$. It seemed that the presence and role of each seagrass species is depend on the environment condition. $H$. uninervis species has the most considerable role in the seagrass community at the site 1 , while the $C$. rotundata species has the largest role in the site 2 . This species can survive well under the conditions of site 1 , but not at the second site because of the environmental condition. $C$. rotundata has good adaptability that can live and grow in polluted conditions (site 2 ) due to its adaptability. The
Iow IVI value of $C$. rotundata at the first site is likely due to the scramble for food between seagrass species in a community that has been pre-dominated by $H$. uninervis. Furthermore, Rasheed et al. (2014) revealed that Halophilla spp. that inhabits in deep water has good capacity to recover from disturbance or damage.

\section{Distribution pattern of seagrass}

Distribution pattern of seagrass in Harapan Island are presented in Table 3. The distribution pattern of $C$. rotundata and $T$. hemprichii at both sites are uniform, except for the Halodule uninervis that found clustered at site 1 and uniformly distributed at site 2. Uniform pattern distribution in site 2 showed that the species grow dominantly, and the site has low diversity. It also indicates that the water conditions at site 2 are disrupted and less supportive for seagrass. Seagrass's ability to colonize surrounding habitats is influenced by tolerance and variability to its abiotic environment (Kilminster et al., 2015). 
ILMU KELAUTAN: Indonesian Journal of Marine Sciences March 2022 Vol 27(1):20-28

Table 2. The average of Important Value Index of seagrass in Harapan Island

\begin{tabular}{lllllll}
\hline \multirow{2}{*}{ Species of Seagrass } & \multicolumn{3}{c}{ RF $(\%)$} & \multicolumn{2}{c}{ RD (\%) } & \multicolumn{1}{c}{ IVI } \\
\cline { 2 - 7 } & Site 1 & Site 2 & Site 1 & Site 2 & Site 1 & Site 2 \\
\hline C. rotundata & 0.32 & 62.6 & 0.32 & 62.6 & 0.64 & 125.2 \\
C. serrulate & 9.3 & - & 9.3 & - & 18.6 & - \\
H. uninervis & 57.4 & 15.27 & 57.4 & 15.27 & 114.8 & 30.53 \\
S. isoetifolium & 13.73 & - & 13.73 & - & 27.46 & - \\
T. hemprichii & 19.24 & 22.12 & 19.24 & 22.12 & 38.5 & 44.25 \\
\hline Total & 100 & 100 & 100 & 100 & 200 & 200 \\
\hline
\end{tabular}

Description: RF (Relative frequency); RD (Relative density); IVI (Important Value Index)

Table 3. Distribution pattern of seagrass in two study sites in Harapan Island

\begin{tabular}{lllll}
\hline \multirow{2}{*}{ Species of Seagrass } & \multicolumn{3}{c}{ Morisita Index } & Description \\
\cline { 2 - 5 } & Site 1 & Site 2 & Site 1 & Site 2 \\
\hline C. rotundata & -3 & 0.87 & Uniform & Uniform \\
C. serrulate & 1.56 & - & Clustered & - \\
H. uninervis & 1.48 & 0.48 & Clustered & Uniform \\
S. isoetifolium & 1.14 & - & Clustered & - \\
T. hemprichii & 0.46 & -0.03 & Uniform & Uniform \\
\hline
\end{tabular}

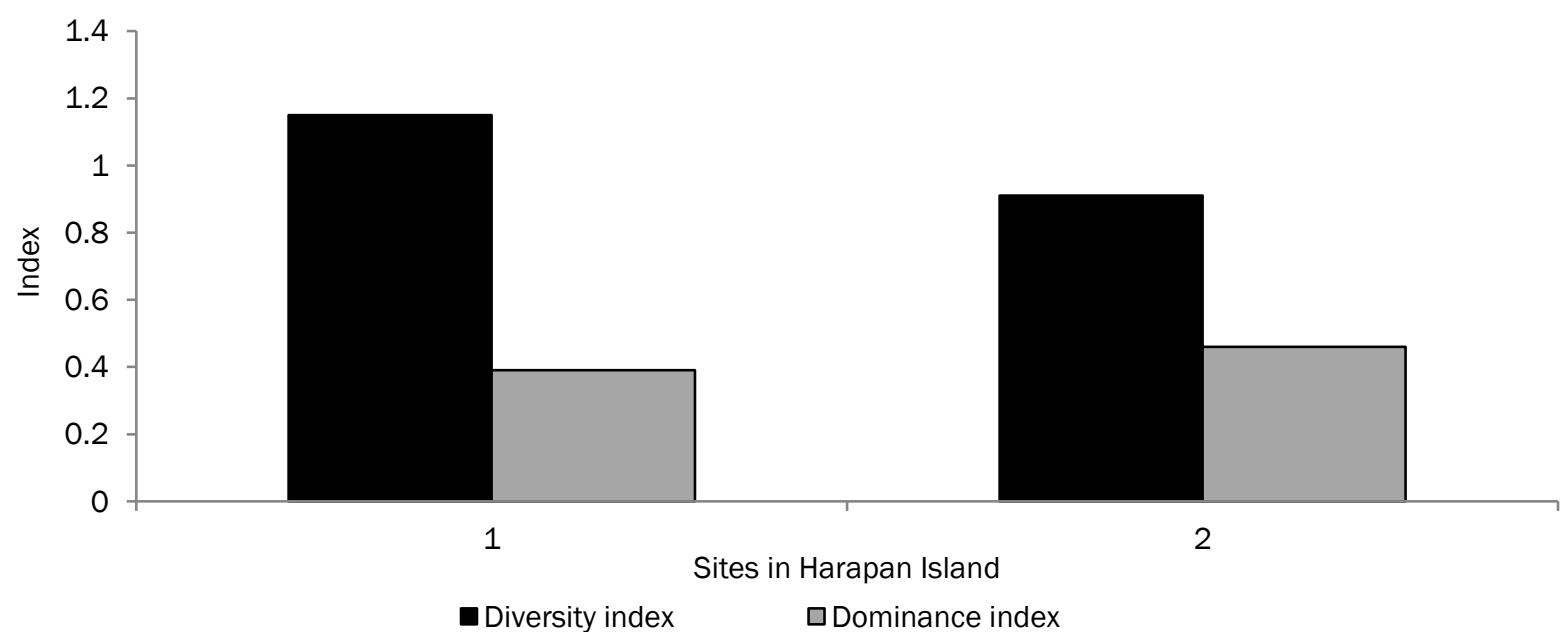

Figure 5. The average of diversity and dominancy index of seagrass in Harapan Island

\section{Water quality parameter}

Water quality parameter in Harapan Island during research are presented in Table 4. Water parameter in site 1 was higher in temperature with lower depth than it was in site 2. Dissolved oxygen in site 1 was also higher than site 2 . It might because site 2 had higher organic compound than site 1. Therefore the water parameter in site 1 was better than site 2.

Natural and anthropogenic disturbance affect the seagrass ecosystem. The measured water temperature at site 1 and 2 are within the optimal temperature of seagrass. Temperatures above $40^{\circ} \mathrm{C}$ will decrease growth and may even result in seagrass deaths (Collier and Waycott, 2014). Because rising of temperature and exposure desiccation impact on declination of photosynthetic rate (Aboud and Kannah 2017). The measured salinity and $\mathrm{pH}$ at both sites is relatively low because of rainy season which caused lower salinity and $\mathrm{pH}$. Refer to Copertino et al. (2016), the changes in salinity affect in physiological stress, while acidification affect on photosynthetic response. The turbidity also good because it clear to the bottom. Meanwhile, Ahmad-Kamil et al. (2013) stated that turbidity correlated significantly to seagrass percentage cover. High turbidity increased sedimentation that covering the seagrass affected on its photosynthesis ability (Soe-Htun et al. 2017). 
Tabel 4. Water quality parameter in Harapan Island

\begin{tabular}{|c|c|c|c|c|c|c|c|c|}
\hline \multirow{2}{*}{ Site } & \multicolumn{2}{|c|}{ Temperature $\left({ }^{\circ} \mathrm{C}\right)$} & \multirow{2}{*}{$\begin{array}{l}\begin{array}{l}\text { Depth } \\
(\mathrm{cm})\end{array} \\
\end{array}$} & \multirow{2}{*}{ Turbidity } & \multirow{2}{*}{$\begin{array}{l}\text { Salinity } \\
\text { (ppt) }\end{array}$} & \multirow{2}{*}{$\mathrm{pH}$} & \multirow{2}{*}{ DO } & \multirow{2}{*}{ Organic Compound } \\
\hline & Water & Air & & & & & & \\
\hline Site 1 & 30,67 & 28,73 & 18,47 & Clear to the bottom & 32,84 & 6,65 & 4,02 & 44,28 \\
\hline Site 2 & 27,96 & 23,98 & 14,4 & Clear to the bottom & 32,53 & 6,61 & 2,42 & 45,336 \\
\hline
\end{tabular}

Grech et al. (2011) describe that anthropogenic activities and their effects on seagrass are caused by waste produced by agriculture, domestic, industrial, and development of settlements and ports in coastal areas. The water conditions at the site 1 tend to be optimal for seagrass since reclamation or construction of residential foundations is not observed. Instead, the mangroves could be found on the north side of site 1 , close to the beach. Meanwhile, no vegetation was found around the site 2. Furthermore, reclamation and ships anchoring at the second site causing damage to seagrass habitat. Evans et al. (2018) stated that the Seagrass damage can be more severe because of human activities e.g. boating, dredging, dumping, bottom trawling, hazardous wastes pollution, tourism, reclamation (Soe-Htun et al. 2017; Evans et al. 2018; Karlina et al. 2018; Riniatsih et al., 2021). In site 2 also has higher organic compound than site 1 , that might be caused site 2 is nearer from residential area therefore produced more household waste and nutrient load which contain nitrogen and phosphorus. Meanwhile, Joseph et al. (2018) reported that the high of nitrate impacts on decreasing of seagrass coverage and growth.

Low diversity in the site 2 is also affected by the pollution since the waters at this site are dominated by the waste in the form of foam and moss floating on the water surface, thus blocking sunlight from entering the water, disrupting the light source for photosynthesis. Collier et al. (2012) state that light penetration affects seagrass abundance and diversity. However, seagrass growth is also limited by nutrient supply and temperature to carry out photosynthesis (Collier et al., 2012). The widespread anthropogenic impacts threaten seagrass habitats and change the balance of ecosystems in coastal areas (Yaakub et al., 2018). Increased degradation of seagrass ecosystems will increase habitat fragmentation (Ricart et al., 2015). Recovery of seagrass ecosystem conditions from damage is affected by the species type and habitat location of the species (Rasheed et al., 2014).

\section{Conclusion}

The percent coverage of seagrass is frequentmoderate coverage. The diversity in site 1 is higher that categorized as moderate and low dominancy. The distribution pattern of seagrass in site 1 is clustered and uniform, while site 2 is uniform. Important Value Index in site 1 is $H$. uninervis, while site 2 is $C$. rotundata. Seagrass ecosystem in Harapan Island need more concern to reduce anthropogenic impact and human activities for supporting environmental coastal and fisheries sustainability.

\section{Acknowledgement}

This research was supported by Faculty of Agriculture Universitas Gadjah Mada. Thanks for Satria Bagus Nuringtyas for making map of studi site in this research.

\section{References}

Aboud, S.A. \& Kannah, J.F. 2017. Abundance, distribution and diversity of seagrass species in Lagonal reefs on the Kenyan Coast. Am. Sci. Res. J. Eng., Technol. Sci., 37(1): 52-67.

Ahmad-Kamil, E.I., Ramli, R., Jaaman, S.A., Bali, J. \& Al-Obaidi, J.R. 2013. The effects of water parameters on mothly seagrass percentage cover in Lawas, East Malaysia. Sci. World J., Article ID 892746. https://doi.org/10.1155/ 2013/892746

Brower, J.E., Zar, J.H. \& von Ende, C. 1998. Field and laboratory methods for general ecology. Illinois, USA: Wm. C. Brown Company Publishers.

Collier, C.J., Waycott, M. \& McKenzie, L.J. 2012. Light tresholds derived from seagrass locc in the coastal zone of the northern Great Barrier Reef, Australia. Ecol. Indic., 23: 211-219. https://doi.org/10.1016/j.ecolind.2012.04.005

Collier, J.C. \& Waycott, M. 2014. Temperature extremes reduce seagrass growth and induce mortality. Mar. Poll. Bull., 83: 483-490. https://doi.org/10.1016/j.marpolbul.2014.03.050

Copertino, M.S., Creed, J.C., Lanari, M.O., Magalhaes, K., Barros, K., Lana, P.C., Sordo, L. \& Horta, P.A. 2016. Seagrass and submerged aquatic vegetation (VAS) habitats of the coast of Brazil: state of knowledge, conservation and main threats. Braz. J. Oceanogr., 64: 53-80. 
https://doi.org/10.1590/S1679-8759201610 36064 sp2

Evans, S.M., Griffin, K.J., Blick, R.A., Poore, A.G.B. \& Verges, A. 2018. Seagrass on the brink: decline of threatened seagrass Posidonia australis continues following protection. PLOS ONE 13(4): e0190370. journal.pone.0190370

Fitrian, T., Kusnadi, A. \& Persilette, R.M. 2017. Seagrass community structure of Tayando-Tam Island, Southeast Moluccas, Indonesia. Biodiversitas. 18(2): 788-794. https://doi.org/ 10.13057/biodiv/d180250

Grech, A., Coles, R. \& Marsh, H. 2011. A broad-scale assessment of the risk to coastal seagrassess from cumulative threats. Mar. Policy. 35: 560567. https://doi.org/10.1016/j.marpol.20 11.03.003

Hartati, R., Widianingsih, W., Trianto, A., Zainuri, M. \& Ambariyanto, A. 2017. The abundance of prospective natural food for sea cucumber Holothuria atra at Karimunjawa Island waters, Jepara, Indonesia. Biodiversitas, 18(3), 947953.

Haviarini, C.P., Azahra, F.A. Refaldi, B. \& Sofyan, O.H. 2019. Konservasi jenis lamun di kawasan perairan Pulau Pramuka, Kepulauan Seribu, Provinsi DKI Jakarta. Jurnal Geografi Gea. 19(1): 42-47.

Irawan, A., Supriharyono, S., Hutabarat, J. \& Ambariyanto, A. 2018. Seagrass beds as the buffer zone for fish biodiversity in coastal water of Bontang City, East Kalimantan, Indonesia. Biodiversitas, 19(3), 1044-1053.

Joseph, L., Singh, P., Singh, A.A., Raj, K. \& Maharaj, A. 2018. Implication of seagrass ecosystem degradation on marine resources and people's livelihood: a case study from Komave Village, Fiji. Asian J. Fish. Aquat. Res., 2(3): 1-14. https://doi.org/10.9734/ajfar/2018/v2i330011

Karlina, I., Kurniawan, F. \& Idris F. 2018. Pressures and status of seagrass ecosystem in the coastal areas of North Bintan, Indonesia. E3S Web Conf. 47: 04008. https://doi.org/10.10 51/e3sconf /20184704008

Kilminster, K., McMahon, K., Waycott, M., Kendrick, G.A., Scanes, P., McKenzie, L., O'Brien, K.R., Lyons, M., Ferguson, A., Maxwell, P., Glasby, T. \& Udy, J. 2015. Unravelling complexity in seagrass systems for management: Australia as a microcosm. Sci. Total Environ., 534: 97-109. https://doi.org/10.1016/j.scitotenv.2015.04.061

LIPI. 2016. Lamun, Penopang Ekosistem Laut yang Sering Terlupa. http://lipi.go.id/lipimedia/la mun-penopang-ekosistem-laut-yang-seringterlupa/15184. Accessed on Dec 30 2021.

McCloskey, R.M. \& Unsworth R.K.F. 2015. Decreasing seagrass density negatively influences associated fauna. PeerJ. 3:e1053; https://doi.org/10.7717/peerj.1053

McRoy, C.P. \& McMillan. 1977. Production ecology and physiology of seagrass, In McRoy, C. P. \& Helfferich (Eds). Seagrass ecosystem, a scientific perspective. Marcel Dekker, Inc. New York.

Pham, L.T., Biber, P.D. \& Carter, G.A. 2014. Seagrasses in the Mississippi and Chandeleur sounds and problems associated with decadalscale change detection. Gulf of Mexico Science. 32(1): 24-43. https://doi.org/10.18785/goms. 3201.03

Rahmawati, S., Irawan, A., Supriyadi, I. H. \& Azkab, M.H. 2014. Panduan Monitoring Padang Lamun. Hutomo, M. \& Nontji, A. (eds). CRITC COREMAP LIPI.

Rasheed, M.A., McKenna, S.A., Carter, A.B. \& Coles, R.G. 2014. Contrasting recovery of shallow and deep water seagrass communities following climate associated lossess in tropical north Queensland, Australia. Mar. Poll. Bull., 83: 491-499. https://doi.org/10.1016/j.marpolbul.2014.02.013

Ricart, A.M., York, A.P., Rasheed, M.A., Pérez, M., Romero, J., Bryant, C.V. \& Macreadie, P.I. 2015. Variability of sedimentary organic carbon in patchy seagrass landscapes. Mar. Poll. Bull., 100: 476-482. https://doi.org/10.1016/j.mar polbul.2015.09.032

Riniatsih, I., Ambariyanto, A., Yudiati, E., Hartati, R., Widianingsih, W. \& Mahendrajaya, R.T. 2019. Diversity species and condition of seagrass ecosystem in Teluk Awur and Prawean Jepara. In IOP Conference Series: Earth and Environmental Science, 236(1): 012052). IOP Publishing.

Riniatsih, I., Ambariyanto, A., Yudiati, E., Redjeki, S. and Hartati, R., 2021. Monitoring the seagrass ecosystem using the unmanned aerial vehicle (UAV) in coastal water of Jepara. In IOP Conference Series: Earth and Environmental Science. 674(1): 012075). IOP Publishing. 
Scott, A.L., York, P.H., Duncan, C., Macreadie, P.I., Connoly, R.M., Ellis, M.T., Jarvis, J.C., Jinks, K.I., Marsh, H. \& Rasheed, M.A. 2018. The role of Herbivory in structuring tropical seagrass ecosystem service delivery. Front. Plant Sci., 9: 127. https://doi.org/10.3389/fpls.2018.00127

Short, F., Carruthers, T., Dennison, W. \& Waycott, M. 2007. Global seagrass distribution and diversity: A bioregional model. J. Exp. Mar. Biol. Ecol., 350: 3-20. https://doi.org/10.1016/j. jembe.2007. 06.012

Soe-Htun, U., Maung, A., Mon, S., Ha, S.T., Aung, S.T., Lwin, A.M. \& Lunn, U.Z. 2017. Biodiversity, distribution and coverage of seagrassess in the Myeik Archipelago and Rakhine coastal areas, in Myanmar. J. Aquac. Mar. Biol., 6(4): 00164. https://doi.org/10.15406/jamb.2017.06.00164

Sugianti, Y. \& Mujiyanto, M. 2020. Current Status and Species Diversity of Seagrass in Panjang Island, Banten. ILMU KELAUTAN: Indonesian Journal of Marine Sciences, 25(1): $15-22$ doi:10.14710/ik.ijms.25.1.15-22

Tebaiy, S., Mampioper, D.C., Batto, M., Manuputty, A., Tuharea, S. \& Clement, K. 2021. The Status of Seagrass Health: Supporting Sustainable Small-
Scale Fisheries in Misool Marine Protected Area, Raja Ampat, Indonesia. ILMU KELAUTAN: Indonesian Journal of Marine Sciences, 26(3): 136-146 doi:10.14710/ik.ijms.26.3.136-146

Tupan, C.I. \& Uneputty, P.A., 2018. Growth and production of leaves Thalassia hemprichii on the Suli coastal waters, Ambon Island. Int. J. Mar. Engineering Innovation and Res., 2(2): 112-116.

Unsworth, R.K.F., McKenzie, L.J., Collier, C.J., CullenUnsworth, L.C., Duarte, C.M., Eklof, J.S., Jarvis, J.C., Jones, B.L. \& Nordlund, L.M. 2019. Global challenges for seagrass conservation. Ambio. 48: 801-815. https://doi.org/10.1007/s132 80-018-1115-y

Van Dam, B.R., Lopes, C.C., Polsenaere, P., Price, R.M., Rutgersson, A. \& Fourqurean, J.W. 2020. Water temperature control on $\mathrm{CO}_{2}$ flux and evaporation over a subtropical seagrass meadow revealed by atmosheric eddy covariance. Limnol. Oceanogr., 66(2): 510-527. https://doi.org/10.1002/Ino.11620

Yaakub, S.M., Ooi, J.L.S., Buapet, P. \& Unsworth, R.K.F. 2018. Seagrass research in Southeast Asia. Botanica Marina. 61(3): 177-179. https://doi.org/10.1515/bot-2018-0046 